Discussion Paper No. 04-31

\title{
Worker Remittances and Capital Flows to Developing Countries
}

Claudia M. Buch and Anja Kuckulenz

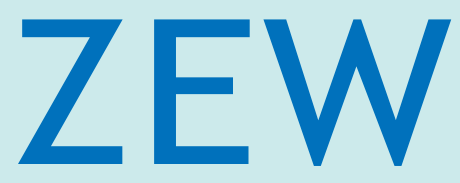

Zentrum für Europäische Wirtschaftsforschung $\mathrm{GmbH}$

Centre for European

Economic Research 
Discussion Paper No. 04-31

\title{
Worker Remittances and Capital Flows to Developing Countries
}

\author{
Claudia M. Buch and Anja Kuckulenz
}

Download this ZEW Discussion Paper from our ftp server:

\author{
ftp://ftp.zew.de/pub/zew-docs/dp/dp0431.pdf
}

Die Discussion Papers dienen einer möglichst schnellen Verbreitung von neueren Forschungsarbeiten des ZEW. Die Beiträge liegen in alleiniger Verantwortung der Autoren und stellen nicht notwendigerweise die Meinung des ZEW dar.

Discussion Papers are intended to make results of ZEW research promptly available to other economists in order to encourage discussion and suggestions for revisions. The authors are solely responsible for the contents which do not necessarily represent the opinion of the ZEW. 


\section{Non-Technical Summary}

Worker remittances constitute an increasingly important mechanism for the transfer of resources from developed to developing countries, and remittances are the second-largest source, behind foreign direct investment, of external funding for developing countries. Yet, literature on worker remittances has so far focused mainly on the impact of remittances on income distribution within countries, on the determinants of remittances at a micro-level, or on the effects of migration and remittances for specific countries or regions. One shortcoming of the existing literature on worker remittances is thus that it mainly relies on microeconomic studies and, therefore, does not fully address the main questions of our current study. We use a large panel data set including 87 developing countries, for which information was generally available from 1970 to 2000 .

Overall, private capital inflows to developing countries are more than three times higher than remittances. However, several countries have experienced a significant expansion of remittances, when comparing it to growth rates of other capital inflows, and during the last three decades, streams of remittances to developing countries increased tremendously, especially in the 1970s and 1980s. We show that remittances, private, and official capital flows have different determinants and, in particular, behaved quite differently over time. To some extent, however, remittances also share similarities with the two types of capital flows considered. These similarities are in fact not surprising since payments of migrants to their relatives back home are motivated both by market-based considerations and by social considerations.

We provide evidence for the thesis that worker remittances provide a stable inflow of money to the receiving country, compared to other capital inflows. 


\title{
Worker Remittances and Capital Flows to Developing Countries*
}

\author{
Claudia M. Buch (University of Tuebingen and Kiel Institute for World Economics) \\ Anja Kuckulenz (Centre for European Economic Research)
}

April 2004

\begin{abstract}
Worker remittances constitute an increasingly important mechanism for the transfer of resources from developed to developing countries, and remittances are the second-largest source, behind foreign direct investment, of external funding for developing countries. Yet, literature on worker remittances has so far focused mainly on the impact of remittances on income distribution within countries, on the determinants of remittances at a micro-level, or on the effects of migration and remittances for specific countries or regions. The focus of this paper is thus on four questions: First, how important are worker remittances to developing countries in quantitative terms? Second, what are the determinants driving worker remittances? Third, how volatile are worker remittances to developing countries? Fourth, are remittances correlated to other capital flows?
\end{abstract}

Keywords: $\quad$ remittances, capital flows, developing countries

JEL classification: F22, F36, J61

* Corresponding author is Claudia M. Buch, University of Tuebingen, Mohlstr. 36, 72074

Tuebingen, Germany. Telephone: +49-7071-2978166 Fax: +49-7071-29 5071

E-mail:claudia.buch@uni-tuebingen.de. We thank Melanie Arntz, Bernhard Boockmann and

Wolfgang Franz for helpful comments on an earlier version of this paper. 


\section{Motivation}

Worker remittances constitute an increasingly important mechanism for the transfer of resources from developed to developing countries (Russell 1992) and are the second-largest source, behind foreign direct investment, of external funding for developing countries (Ratha 2003). Therefore, developing countries are often in the focus of the discussion since worker remittances tend to be fairly unimportant for more developed countries. Yet, literature on worker remittances has so far focused mainly on the impact of remittances on income distribution within countries, on the determinants of remittances at a micro-level, or on the effects of migration and remittances for specific countries or regions.

Our research differs from earlier work in three main regards. First, rather than providing case study evidence, we give a broader view, using panel data for a large cross-section of countries for the past three decades. Second, we do not only study the determinants of remittances but we also view remittances as one type of capital flow to developing countries, and we compare the determinants of remittances to those of private and official capital flows. Third, while former research typically defines remittances as the sum of worker remittances (payments from workers who have lived abroad for more than one year), compensation of employees or labor income (payments from workers who have lived abroad less than one year), and migrant's transfers ${ }^{1}$, we use data on workers' remittances only. We focus on this narrow definition and concentrate on workers' remittances to developing countries because we do not want to mix different motivations to remit. ${ }^{2}$

The focus of this paper is thus on four questions:

First, how important are worker remittances to developing countries in quantitative terms? We provide evidence on the magnitude of remittances relative to key macro-economic variables such as gross domestic product, international trade, and international capital flows.

Second, what are the determinants driving worker remittances? The paper focuses on main macroeconomic determinants of remittances. We use a large cross-section comprising 87 developing countries as well as panel data for these countries with information generally available from 1970 to 2000 . The determinants of worker remittances are compared to those of private capital flows and official capital flows.

1 E.g. Ratha (2003)

2 While developing countries usually report worker remittances, developed countries report compensation of employees. Migrants from developing countries who remit can be generally classified as low- or medium-skilled workers. Many of the employees from developed countries who work abroad for one year are high-skilled workers. From an aggregate point of view, the motivation to remit for the two groups might be very different. 
Third, how volatile are worker remittances to developing countries? We compare the volatility of remittances to the volatility of other types of capital flows. One prior of our analysis is that remittances could be more stable than private capital flows, and that they might even provide a stabilizing element during periods of financial instability.

Fourth, are remittances correlated to other capital flows? From a theoretical background, we could expect workers' remittances to be negatively correlated with private capital flows. If the motives for sending remittances are related to households' budget constraints, migrants might try to shield their families against adverse domestic shocks by increasing the flow of remittances whenever private capital flows become more scarce. Remittances might thus behave quite similar to aid and we, therefore, might expect workers' remittances to be positively correlated to official capital flows.

The paper is structured as follows. In the following second part, we briefly review the theoretical and empirical macroeconomic literature on workers' remittances. In part three, we present our own empirical evidence. We compare remittances to private and official capital flows in terms of magnitude, their determinants, and their volatility, and we provide a correlation analysis between the different types of flows. Finally, we conclude with a summary of our results and an outlook for future research.

\section{The Economics of Worker Remittances}

There is a vast body of theoretical and empirical literature explaining the motivations of migrants to remit money to their relatives at home and the impact of remittances on the recipient communities. Many of these contributions have a microeconomic focus. Since, in this paper, we focus on the macroeconomic determinants of remittances as compared to those of private and official capital flows, we select the papers that we review in the following accordingly. ${ }^{3}$

\subsection{Theoretical Models}

While former work has emphasized costs and benefits of worker remittances, recently, the determinants and effect of remittances have moved into the focus of the discussion. Macroeconomic models have, on the one hand, stressed the positive impact of worker remittances on the current account since they provide both foreign exchange and additional savings for economic development. With remittances, an economy can spend more than it produces, import more than it exports or invest more than it saves, and this might even be more relevant for small economies (Connell and Conway 2000). On the other hand, remittances might perpetuate an economic dependency that undermines the prospects for development. Recipients can become accustomed to

3 An overview of the relevant microeconomic literature can be found in Stark and Bloom (1985), Taylor (1999) or Buch et al. (2002). 
the availability of these funds and there can develop a continuing trend of migration of working age population. Additionally, the literature has emphasized the potential occurrence of "Dutch disease" effects which can deteriorate the economy's payment position and worsen the welfare of families not receiving remittances (McCormick and Wahba 2000). Developing countries are often in the focus of the discussion since remittances are relatively large compared to other capital inflows. In contrast, worker remittances tend to be fairly unimportant for more developed countries.

As regards the determinants of worker remittances, several macroeconomic factors have been singled out in the literature. The black market foreign exchange premium and the presence of domestic banks in the host country have been identified to strongly affect the size of officially registered remittances (El-Sakka and McNabb 1999, Karafolas 1998, Russell 1992). Additionally, remittances are responsive to changes in the interest rate differential between home and host country, government policies, the level of economic activity both in the host and in the home country, wages, political risk factors in the sending country, and the rate of inflation. Also, the magnitude of remittances is influenced by the number of migrant workers abroad as well as by the number and characteristics of their families, and the share of temporary migrants in total migrants (Russell 1986, Russell 1992).

\subsection{Previous Empirical Evidence}

Much of the available empirical evidence on remittances is at the microeconomic level, based on survey data. Mainly, the determinants and the uses of remittances have been discussed. Literature on the implications of remittances on the overall economy is much less rich. ${ }^{4}$

Several microeconomic studies indicate that the education and the income level of the migrant and his family are the main determinants of remittances. Durand et al. (1996) show that important determinants shaping the amount remitted include the migrant's wage and job situation, the number of dependents at home, marital status, and age of the migrant. Brière et al. (2002) use Dominican data to examine the two main motives to remit, i.e. the intention to insure relatives at home against changes in income and the intention to invest in the home country. They find that the factors determining the magnitude of remittances are the migrants' destination, gender, and household composition. The motive of migrants to remit also crucially depends on whether migration is temporary or permanent. For temporary migrants, remittances are often obligatory, while remittances send by permanent migrants are gifts to relatives in the home country (Glytsos 1997). Using the German SOEP, Oser (1996) also provides evidence for behavioral differences between permanent and temporary migrants when deciding to remit. Even though remittances decline when migrants decide to stay in the host country, they continue to send money to their home country. Agarwal and Horowitz (2002) recently tested altruism versus risk sharing motives to remit and gave evidence supporting the altruistic incentive. Due to the fact that there has been extensive migration

4 Taylor et al. (1996a and 1996b) provides an exhaustive review on the empirical literature. 
from small island states, part of the literature concentrates on remittances to these microstates only. Influences of migration and remittances are especially large on island communities, and remittances are an important source of income for these economies. Research has also shown that remittances make a real contribution to both savings and investments of these countries (Brown 1994, Brown 1997, Brown and Ahlburg 1999, Connell and Conway 2000).

The main problem of microeconomic case studies is that they tend to undervalue the macroeconomic impact of remittances by focusing on isolated communities. Therefore, several studies have looked also at the macroeconomic effects of remittances and found that remittances often provide a significant source of foreign currency (El-Sakka 1987, Taylor et al. 1996b). Haderi et. al (1999) find, for instance, that remittances to Albania crucially affect the country's inflation and the exchange rate. For Eastern European countries in transition, León-Ledesma and Piracha (2001) show that remittances have a positive impact on productivity and employment. Banuri (1986) argues that there is also a negative effect on the macroeconomy of the receiving country because remittances abrogate protectionist policies installed by governments in order to protect investment and profit in the industry sector. While overall investment rates increase with the volume of remittances, there can be a Dutch Disease effect if investment shifts from the industrial sector to the agricultural sector. Chami et al. (2003) link the motivation for remittances with their effect on economic activity. They show that the moral hazard problem in remittances is severe and hence their effect on economic growth is negative.

Regarding the macroeconomic determinants of remittances, there is no strong consensus in the literature. Straubhaar (1986) uses Turkish data to show that the size of remittances is influenced by the income situation and the labor market situation in the immigration country and by the home country's political stability. Economic benefits, which are proxied by exchange rate changes and by changes in the real return of investment, did not affect the flows of remittances here. Evidence for India, however, shows that remittances in the form of repatriated deposits grew at a faster rate in response to interest rate differentials created by the fall in international interest rates (Nayar 1989). In his study of remittances of Greek guest workers, Lianos (1997) gives evidence that, along with the income of migrants, inflation rate, exchange rate, interest rate, number of migrants and the unemployment rate, also cohort effects are important in determining the volume of remittances.

Sayan (2004) determines empirical regularities between fluctuations in remittances and the business cycle characteristics in either the countries hosting guest workers or the countries sending them. Data of Turkish guest workers in Germany indicates that real remittances are procyclical with the GDP in Turkey and acyclical with German GNI.

Recently, Gammeltoft (2002) has first attempted to evaluate the magnitude of remittances worldwide. Using panel data, he describes remittances and other financial flows to developing countries and shows trends as well as geographical variations of these flows. 


\section{New Empirical Evidence}

One shortcoming of the existing literature on worker remittances is that it mainly relies on microeconomic studies and, therefore, does not fully address the main questions of our current study. We thus begin by presenting evidence on the magnitude and the determinants of worker remittances received by developing countries using a large panel data set. ${ }^{5}$ Data presented in the following are drawn from a sample of 87 developing countries, for which information was generally available from 1970 to 2000 (Table 1$)^{6}$.

\subsection{Magnitude}

Contrary to earlier predictions that remittances would lose importance over time due to declining migration rates (Macpherson 1992), remittances (measured in 1995 USD) have actually grown more rapidly than international migration flows. During the last three decades, streams of remittances to developing countries increased tremendously, especially in the 1970s and 1980s (Graph 1). Graph 2 shows remittances received in the 1990s by region in comparison to private and official capital flows. Overall, remittances are rather stable over the 1990s in all regions. Latin American and Caribbean countries received increasing amounts of remittances, and their share in world remittances increased. Starting from very high levels of remittances, flows to the North African and Middle Eastern countries decreased but their share in total remittances still exceeds 25 percent of the total. Generally, however, the ranking of countries in terms of their share in global remittances has remained relatively stable with rank correlations of almost 0.9 between the individual decades.

Looking at the importance of remittances on a country-by-country basis shows some interesting patterns in the data. Remittances are above 5\% of GDP for 19 countries in our sample. For a selection of these countries, remittances, private and official capital inflows in the 1990s are shown in Graph 2. Remittances are most important relative to GDP for island states like Tonga and Samoa in the Pacific Ocean, Cape Verde in the Atlantic Ocean, Jamaica, Grenada, St.Vincent and the Grenadines and St. Kitts and Nevis in the Caribbean Sea, and Sri Lanka and Comoros in the Indian Ocean. A second group of countries receiving remittances far above average are some Middle Eastern countries, including Lebanon, Yemen, and Jordan. Half of the Middle Eastern countries in our sample receive more remittances than private capital from abroad. The proximity of these countries to oil-producing OPEC countries and the resulting demand for labor is certainly a

5 We use "worker remittances" received by all countries reported in the IMF Balance of Payments Statistics Yearbook. For a discussion on the measurement of remittances in the IMF statistics and for evidence on the magnitude of world remittances, including "worker remittances", "migrant transfers", and "labour income", see Russell (1992) and Russell and Teitelbaum (1992).

6 We excluded Angola, Anguila, Barbados, Hong Kong, Mongolia, Montserrat, Netherlands Antilles, Solomon Islands, Turkmenistan, and Uruguay due to missing data. 
contributing factor. Finally, some Latin American countries such as El Salvador, Nicaragua, and the Dominican Republic receive large amounts of remittances. Essentially, the same holds for Albania (and to some extent for Croatia), the only European countries for which remittances are of significant importance. The same group of countries is at the top when measuring remittances as a percentage of exports and imports.

Overall, private capital inflows to developing countries are more than three times higher than remittances. The North African and Middle Eastern countries, for instance, received more remittances than private or official capital flows (i.e. foreign aid). The mean value of remittances, of private, and of official capital inflows to developing countries is $0.8,2.6$, and 2.0 percent relative to GDP, respectively. Thus, for most countries in our sample, remittances are lower than private capital flows and official capital inflows. Yet, for 22 countries, remittances are higher than private capital flows and, for 10 countries, remittances are higher than official capital inflows. Thus, for a number of developing countries, such as Albania, Croatia, El Salvador, Samoa, Yemen, and Jordan, remittances exceeded private and official capital inflows, making remittances the principal source of foreign currency.

In addition, most countries have participated in the global increase of financial flows. Private capital inflows, official capital inflows, and remittances for our sample have increased on average over the 1970-2000 period by 195 percent, 93 percent and 242 percent, respectively. Again, regional patterns are diverse across countries: worker remittances grew especially in Latin America and the Caribbean, private capital inflows increased tremendously in the Asia Pacific region, and official capital inflows grew most to countries in Sub-Saharan African and in the Asia Pacific. However, several countries have even experienced a significant expansion of remittances, when comparing it to growth rates of other capital inflows. 52 percent of the countries had higher growth rates of remittances compared to private capital flows and 49 percent had higher growth rates of remittances compared to official capital inflows.

\subsection{Macroeconomic Determinants}

The review of the empirical and theoretical literature above has revealed a list of macroeconomic variables that can be expected to have an impact on the volume of remittances that countries receive. In this section, we provide some more formal evidence on whether these variables can explain some of the large variations in the importance of remittances that we observe across countries. We run panel regressions using remittances over GDP as well as remittances in per-capita terms as the dependent variables. We use the feasible GLS estimator in order to account for autocorrelation and heterogeneity in the data and to be able to include time-invariant effects ${ }^{7}$. We also run the same type of regressions for private and official capital flows over GDP in order to

7 To check for robustness, we also used a fixed effects estimator. Qualitatively, results didn't change much. 
check whether the determinants of remittances and capital flows differ (results are summarized in Table 2).

In a baseline specification, we include GDP growth, (log) GDP per capita, the domestic inflation rate, the spread of the domestic lending rate over libor and a dummy which is equal to one whenever the country is an island (proxy for isolated economy). In addition to estimating our regressions for the full sample, we additionally split the sample into the 1970s, 1980s, and 1990s. This split roughly corresponds to the period characterized by the oil crises of the $1970 \mathrm{~s}$, the period during and after the debt crises of the 1980s, and the globalization period (the 1990s). Additionally, we run regressions including different sets of regressors in order to check the robustness of our results. The dependent variable is scaled by GDP but the qualitative results are the same for the variables scaled by population. To capture regional differences, we include dummies for Latin America and the Caribbean, Asia Pacific, North Africa and the Middle East and Sub-Saharan Africa in some specifications. North America and Europe is included as the reference category.

GDP growth is intended to capture the attractiveness of countries for investment. Hence, the expected impact on private capital flows is positive. For official capital flows (aid), we might expect negative or even insignificant signs since aid might be targeted to countries with low growth. The impact of this variable on remittances is not clear-cut: on the one hand, high growth might reduce the incentives to migrate and, hence, there would be small remittances in countries with high-economic growth. On the other hand, migrants living abroad might want to invest in their high growth home country. Our regression results suggest that these effects of growth on remittance indeed seem to cancel out. There is no significant effect for the full sample, while regressions for each decade tend to show a negative relationship for the 1970s and a positive sign for the 1990s. For official capital flows, we tend to find the expected negative impact of economic growth, while this variable is mostly insignificant for private capital flows (if anything, we find a negative impact in some of the specifications).

The spread of the domestic lending rate over libor has a similar interpretation as GDP growth since it more directly captures the rates of return on domestic financial assets. The variable is mostly insignificant for remittances (with the exception of negative coefficients that we find in some specifications for the 1970s). For private and official capital flow, we also find no significant impact for the full sample under study. This, however, is due to the fact that the interest rate spread had a different impact on these capital flows in the 1980s compared to the 1990s: In the 1980s, official capital flows went mainly into the high interest countries. In the 1990s, in contrast, the impact of the interest rate spread on official capital flows was negative and significant. For private capital flows, we find a significant effect only in the 1980s. In this decade, however, private capital tended to flows into the low-interest developing countries.

GDP per capita is included as a proxy for the general state of the development of countries. Hence, we expect a negative coefficient for remittances since, in more developed countries, incentives to migrate and remit are relatively small. For private capital flows, we expect a positive 
coefficient, since more developed countries also tend to have better financial markets and are thus more attractive from the point of view of investors. For official capital flows and aid, the expected sign is negative, in contrast. This negative effect in fact comes out strongly in the data. For private capital flows, there is a significantly positive impact of GDP per capita in some of the regressions, but evidence is less robust, in particular if some regional dummies are included. For remittances, we find the expected negative coefficient, but this result is driven mainly by the data from the 1990s. In the 1970s and 1980s, we often find an insignificant or even positive impact of GDP per capita on the share of remittances over GDP.

The domestic inflation rate captures the degree of macroeconomic instability. The expected impact on remittances is not clear-cut. While an unstable macroeconomic environment creates incentives to migrate abroad, high inflation might also have a positive impact on remittances. This is because the higher inflation and the greater the uncertainty about future price changes, the lower will be the expected rate of return on money remitted. The expected impact of inflation on remittances would thus be negative. For private capital flows, the expected impact of inflation is somewhat more direct, and we expect a positive sign. The impact of inflation on official capital flows, in contrast, is less clear-cut since donors might to some extent be interested in supporting the population in countries which are macroeconomically unstable.

The empirical results for inflation are relatively weak though. For remittances, we tend to find an insignificant impact, suggesting that the two forces described above cancel out. For official capital flows, there was in fact a trend towards high inflation developing countries in the 1970s. In the 1990s, in contrast, this effect was positive. The net effect for the full sample is insignificant. Finally, there is a positive association between private capital flows and inflation in the 1980s only.

Stylized facts reported above suggest that remittances are important for island countries. We control for this by adding a dummy indicating whether the country is an island or not. The impact on remittances is expected to be positive. Due to their special geographical location, which can inhibit growth, island countries should receive more remittances. The data strongly confirm our presumption in the baseline specification. Island economies receive more official and private capital flows and remittances flows to islands were significantly smaller in the 1970s, while significantly larger in the 1980s and 1990s. In the specification with all control variables, the island coefficient turns insignificant. The impact of the island dummy on official capital flows is positive and there is no impact on private capital flows.

In summary, results of the baseline specification show that remittances, private, and official capital flows have different determinants and have in particular behaved quite differently over time. To some extent, however, remittances also share similarities with the two types of capital flows considered. These similarities are in fact not surprising since payments of migrants to their relatives back home are motivated both by market-based considerations and by social considerations. On the one hand, migrants try to shield their families back home from adverse economic developments. On 
the other hand, migrants have to consider the opportunity costs of sending remittances as an alternative to investing their financial assets abroad.

To shed more light on the possible determinants of remittances and capital flows, we have added to the baseline specification a couple of variables which are intended to capture demographic factors and the structure of the educational system.

We do control, for instance, for the share of females in the labor force. The expected impact on remittances is negative since there is less need to remit money from abroad to women who have stayed behind if women have relatively good employment opportunities ${ }^{8}$. We in fact confirm this result, in particular for the 1980s and 1990s.

We have no strong prior for the effect of female labor force participation for private capital flows and this variable in fact tends to be insignificant (the exception are the 1970s). For official capital flows, the expected impact is ambiguous. On the one hand, the empowerment of women is an important goal of foreign aid programs. Hence, donors might try to target their funds towards countries where the role of females in the workforce is limited. On the other hand, the empowerment of women might be a reason why official aid goes precisely to the countries where women participate in the labor force already. Our results suggest that this second effect dominates: females labor force participation has a positive impact on official capital flows.

We also control for the age dependency ratio which gives the number of dependents to the working age population. The expected coefficient for remittances is positive. This is because there is a higher need for remittances in countries with a high ratio of dependents to working age population. However, we find the opposite: remittances are smaller in countries with a high agedependency ratio. We do find the positive impact of this variable for official capital flows though. To some extent, official capital flows might thus be substituting remittances in these countries. This interpretation would not explain though why a high age-dependency ratio has a negative impact on remittances. The negative relationship could rather be explained with the fact that a high share of dependents has a negative impact on migration and thus, indirectly, on remittances. The higher the share of dependents, the fewer people are in the age group in which people typically migrate. Also, the more dependents a population has, the more difficult does it become for those who could potentially migrate to leave their country. Alternatively, a high age dependency ratio might indicate that the country is more developed and hence, the need for remittances is smaller.

Finally, we include 'illiteracy' as a measure for the education and skill level and as a proxy for the expected wage of migrants. ${ }^{9}$ The expected coefficient is negative since better educated migrants (lower illiteracy) will earn higher wages and are therefore able to remit more. This effect is not confirmed in the data, we mostly find a positive coefficient in our regressions. A possible

8 A high share of females in the labor force can also indicate that the need to migrate is low and hence, remittances are low.

9 Unfortunately, we do not have information on the actual skill level of the migrants. Therefore, we use the overall skill level of the population as a proxy. 
explanation is that illiteracy, which is correlated with GDP per capita, is another proxy for the state of development. Hence, the coefficient is negative since, if illiteracy is high, the need for remittances is high as well. For private and official capital flows, we might expect a negative and positive effect, respectively. Private capital flows will be lower and official capital flows will be higher to countries with high illiteracy rates and hence, a low level of education and development. Due to high correlations with other controlling variables, coefficients change their sign, depending on the specification. In our preferred specification, where all variables are included, we find the expected coefficients for illiteracy.

There are a couple of additional variables that would be interesting to analyze from a theoretical point of view or according to the results of previous studies. However, we decided not to include these variables for the following reasons. Proxies for health such as the degree of human development, the mortality rate, and health expenditures of the government are highly correlated with log GDP per capita. Similarly, school enrollment is highly correlated with illiteracy.

While the above variables have been excluded for econometric reasons, there was also a set of variables for which we did not obtain sufficient data. Data on the number of migrants, for instance, have not been available for a sufficiently large set of countries and a sufficiently long time period. Also, we could not include dummies for financial crises since available datasets do not include a sufficient number of developing countries and/or do not span a sufficiently long time period. For the same reason, we could not include unemployment as a proxy for the level of economic activity of the home country and/or the social situation of home country. With high unemployment, both the incentives to migrate and the need of the migrants families are higher.

\subsection{Correlation Analysis}

Migrants might use remittances as a stabilizing element for the income of their families back home. Therefore, we might expect worker remittances to be negatively correlated to private capital flows. We find that worker remittances are negatively, but not significantly related to private capital inflows when looking at all the countries (Table 3). The correlation analysis gives rather diverse results when looking at regions. For none of the regions, there is a significant (at 5 percent level) correlation between workers' remittances and private capital inflows. Coefficients are divided into positive and negative for the regions. Regarding the correlation of official capital flows and remittances, the picture is much more homogeneous and meets the prediction that remittances should behave similar to official capital inflows. Hence, all regions have a positive correlation between workers' remittances and official capital inflows. Taking all countries together, the correlation is significant with 0.29. For the North America and Europe region, the correlation coefficient is highest with 0.60, followed by Asia Pacific and North Africa and the Middle East. Both regions have a correlation coefficient of 0.51 . The correlation coefficients of Latin America and the Caribbean and Sub-Saharan Africa are 0.30 and 0.20 , respectively. 
Like remittances, we might expect that official capital flows are negatively correlated to private capital inflows in order to provide aid to those regions that have no other (private) sources of capital. This expectation is not confirmed by the data though. Rather, we mostly find significantly positive correlations. Overall, the correlation coefficient is positive and has a value of 0.10 . In both the Asia Pacific region and in Sub-Saharan Africa, private capital inflows are strongly positively correlated to official capital inflows (0.33). For North Africa and the Middle East and for North America and Europe, correlations are 0.25 and 0.22 , respectively. There is a positive, but on a 5 percent level insignificant correlation for Latin America and the Caribbean (Table 3).

Analyzing the correlation between worker remittances and private and official capital flows on a country-by-country angle, we found no clear pattern. The coefficients of correlation between remittances and private capital inflows and between remittances and official capital inflows both range from being highly positive to highly negative numbers. Nevertheless, some trends are visible. For most countries in North America and Europe, we find a positive correlation between remittances and private capital flows while for countries in all other regions, the picture is diverse. In Sub-Saharan Africa, North America and Europe and North Africa and Middle East, most countries exhibit a positive correlation between remittances and official capital flows. In contrast, most countries in Asia Pacific show a negative correlation between remittances and official capital flows.

\subsection{Volatility Analysis}

Comparing the coefficients of variation for worker remittances, official and private capital inflows, variation is highest for private capital inflows, lowest for official capital inflows, and remittances are in-between. Estimating the coefficient of variation of worker remittances to GDP ratio for the 5 regions, we find that variation in remittances are highest for Sub-Saharan Africa and North America and Europe and lowest for Latin America and the Caribbean and North Africa and the Middle East. For official and private capital inflows, variation between countries differs much more than for remittances (Table 4).

Comparing the volatility of remittances, private and official capital inflows for all countries separately, the volatility of remittances are overall clearly lower than the volatility of private and also of official capital inflows. As can be seen in Table 5, for more than 80 percent of the countries in our sample, remittances volatility is lower than private capital inflows volatility and for more than 70 percent of the countries, remittances volatility is lower than official capital inflows volatility. These findings provide evidence for the thesis that worker remittances provide a stable inflow of money to the receiving country, compared to other capital inflows. 


\section{Summary and Outlook}

When discussing the integration of international markets, worker remittances typically receive no special attention. This is due to their hybrid nature as being closely related to the integration of labor markets and yet representing flows of financial capital. In this paper, we have thus taken a fresh look at the characteristics and determinants of worker remittances. In contrast to earlier literature, which has studied worker remittances from a rather microeconomic point of view, we have looked into the macroeconomic nature of remittances. One particular goal of the analysis has been to show whether worker remittances share similarities with private and official capital flows. Since worker remittances are an important phenomenon mainly for developing countries, we have excluded developed countries from our sample.

In a first step, we have studied the stylized facts of worker remittances and capital flows. Worldwide worker remittances have increased during the last decades, especially in Latin America and the Caribbean. North African and Middle Eastern countries have the highest share of worker remittances, around 25 percent of worldwide remittances are received by this group of countries. For 19 countries in the sample, remittances are above 5 percentage points of GDP and hence play an important role in these economies. For most countries though, remittances are smaller than official and private capital inflows. The correlation analysis revealed a positive correlation between worker remittances and official capital inflows and between official capital inflows and private capital inflows, but there is no correlation between remittances and private capital inflows. Volatility of worker remittances is for most countries (more than 80 percent) lower than volatility of private capital inflows and also for the main part (more than 70 percent) it is lower than volatility of official capital inflows.

In a second step, we have used panel regressions to find the determinants of remittances and capital flows. Generally, we find that traditional variables such as economic growth, the level of economic development, and proxies for the rate of return on financial assets do not have a clear impact on the magnitude of remittances that a country receives. One likely explanation for this finding is that worker remittances share features of private and official capital flows, which in turn are driven by quite different factors. In other words, worker remittances are to a large extent market-driven, but social considerations play an important role as well in deciding how much money to remit.

There are a couple of additional, demographic factors that affect worker remittances but not necessarily private and official capital flows. Countries with a high share of female employment, a high age-dependency ratio, and low illiteracy rates, for instance, receive more remittances than comparable developing countries. The impact of these variables of remittances, in turn, is often an indirect effect that works through their impact on migration.

In future work, it would be interesting to explore the hybrid nature of remittances in more depth. It would, for instance, be interesting to control for the impact of migration on remittances. In 
addition, the stylized facts presented in this paper suggest that remittances might have stabilizing features during episodes of financial crises. Case-study evidence on countries undergoing financial crises might be useful to further study this feature.

\section{References}

Agarwal, Reena and Horowitz, Andrew (2002). Are International Remittances Altruism or Insurance? Evidence from Guyana Using Multiple-Migrant Households. World Development 30 (11): 2033-2044.

Banuri, Tariq Javed (1986). Macroeconomic Effects of Worker Remittances. Ph.D-thesis, Harvard University, Cambridge, Massachusetts.

Brière, de la Bénédicte et al. (2002). The roles of Destination, Gender, and household composition in explaining remittances: an Analysis for the Dominican Sierra. Journal of Development Economics 68: 309-328.

Brown, Richard (1994). Migrants' remittances, savings and investment in the South Pacific. International Labour Review 133(3): 347-367.

Brown, Richard (1997). Estimating Remittance functions for Pacific Island Migrants. World Development 25 (4): 613-626.

Brown, Richard and Dennis Ahlburg (1999). Remittances in the South Pacific. International Journal of Social Economics 26: 325-344.

Buch, Claudia, Anja Kuckulenz and Marie-Hèlène Le Manchec (2002). Remittances and Capital Flows. Kiel Working Paper No. 1130, Kiel Institute for World Economics.

Chami, R., C. Fullenkamp and S. Jahjah (2003). Are Immigrant Remittance Flows a Source of Capital for Development? IMF Working Paper 03/189, Washington, DC.

Connell, John, and D. Conway (2000). Migration and Remittances in Island Microstates: A Comparative Perspective on the South Pacific and the Caribbean. International Journal of Urban and Regional Research 24: 52-78.

Durand, J., W. Kandell, E. Parrado, and D.S. Massey (1996). International Migration and Development in Mexican Communities. Demography 33 (2): 249-64.

El-Sakka, M.I.T. (1987). Migrant Remittances and the Balance of Payments: The Egyptian Case. Population Studies vol.13 no.74: 87-106.

El-Sakka, M.I.T., and R. McNabb (1999). The Macroeconomic Determinants of Emigrant Remittances. World Development 27 (8): 1493-1502.

Gammeltoft, Peter (2002). Remittances and other Financial Flows to Developing Countries. CDR Working Paper 02.11, Copenhagen.

Glytsos, Nicholas (1997). Remitting Behaviour of "Temporary" and "Permanent" Migants: The Case of Greeks in Germany and Australia. Labour 11 (3): 409-435.

Haderi, Sulo, H. Papapanagos, P. Sanfey, and M. Talka (1999). Inflation and Stabilization in Albania. Post-Communist Economies 11 (1): 127-141.

International Monetary Fund (IMF) (2002a). Balance of Payments Statistics. CD-ROM. Washington, D.C. 
International Monetary Fund (IMF) (2002b). International Financial Statistics. CD-ROM. Washington, D.C.

Karafolas, Simeon (1998). Migrant Remittances in Greece and Portugal: Distribution by country of provenance and the role of the banking presence. International Migration 36(3): 357-381.

Korovilas, James (1999). The Albanian Economy in Transition: the Role of Remittances and Pyramid Investment Schemes. Post-Communist Economies 11(3): 399-415.

Lianos, T.P. (1997). Factors determining Migrant Remittances: The Case of Greece. International Migration Review 31 (1): 72-87.

León-Ledesma, Miguel and Matloob Piracha (2001). International Migration and the Role of Remittances in Eastern Europe. University of Kent, Department of Economics. Discussion Paper 01,13.

Macpherson, C. (1992). Economic and political restructuring and the sustainability of migrant remittances: The case of Western Samoa. The Contemporary Pacific 4 (1): 109-135.

McCormick, B., and J. Wahba (2000). Overseas Employment and Remittances to a Dual Economy. The Economic Journal 110 (April): 509-534.

Nayyar, Deepak (1989). International Labour Migration from India: A Macro-Economic Analysis. In To the Gulf and Back Migration: Studies on the Economic Impact of Asian Labour migration, edited by Rashid Amjad (pp. 95-142). Geneva: International Labour Office.

Oser, Ursula (1996). Arbeitskräftewanderungen und Überweisungen: Eine theoretische und empirische Analyse der finanziellen Transfers von Gastarbeitern in ihre Heimatländer. Verlag für Wissenschaft und Forschung, Berlin.

Ratha, D. (2003). Worker's Remittances: An Important and Stable Source of External Development Finance. (Chapter 7) in Global Development Finance: Striving for Stability in Development Finance, Washington, DC: World Bank, pp. 157-175.

Russell, Sharon S. (1986). Remittances from International Migration: A Review in Perspective. World Development 14 (6): 677-96.

Russell, Sharon S. (1992). Migrant Remittances and Development. International Migration: Quarterly Review 30 (3): 267-287.

Russell, Sharon S. and M.S. Teitelbaum (1992). International Migration and International Trade. The World Bank, World Bank Discussion Paper No.160, Washington, D.C.

Sayan, S. (2004). Guest Workers' Remittances and Output Fluctuations in Host and Home Countries: The Case of Remittances from Turkish Workers in Germany. Forthcoming in Emerging Markets Finance and Trade.

Stark, O., and D. Bloom (1985). The new economics of labor migration. American Economic Review 75:173-8.

Straubhaar, T. (1986). The Determinants of Remittances: the Case of Turkey. Weltwirtschaftliches Archiv 122 (4): 728-40.

Taylor, J.E., J. Arango, G. Hugo, A. Kouaouci, D. Massey, and A. Pellegrino (1996a). International Migration and National Development. Population Index 62 (2): 181-212.

Taylor, J.E., J. Arango, G. Hugo, A. Kouaouci, D. Massey, and A. Pellegrino (1996b). International Migration and Community Development. Population Index 62 (3): 397-418.

Taylor, J.E. (1999). The New Economics of Labour Migration and the Role of Remittances in the Migration Process. International Migration 37 (1): 63-88.

World Bank (2002). World Development Indicators. CD-ROM. Washington D.C. 


\section{Appendix I: Graphs and Tables}

Graph 1 - Total Workers' Remittances per Capita in Constant (1995) US Dollar

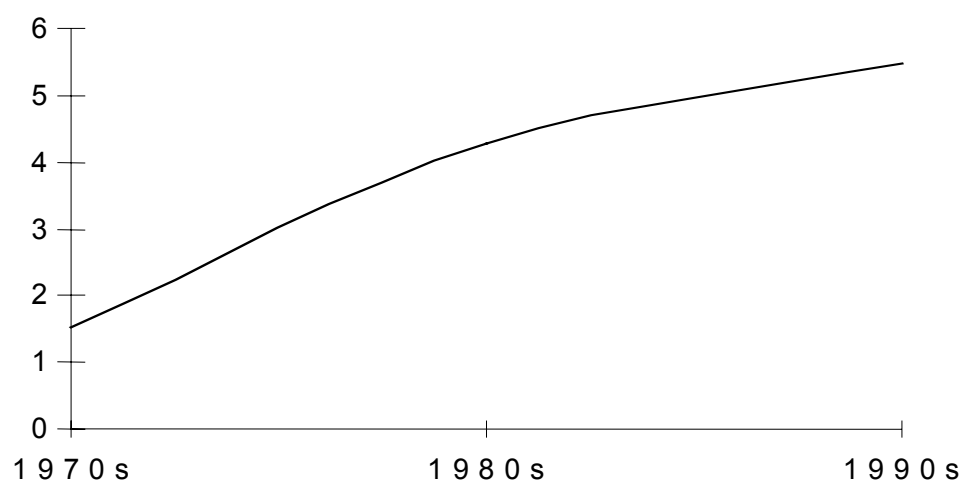


Graph 2 - Workers' Remittances, Private, and Official Capital Flows (in \% of GDP) in the 1990s

a) By Region

Asia Pacific

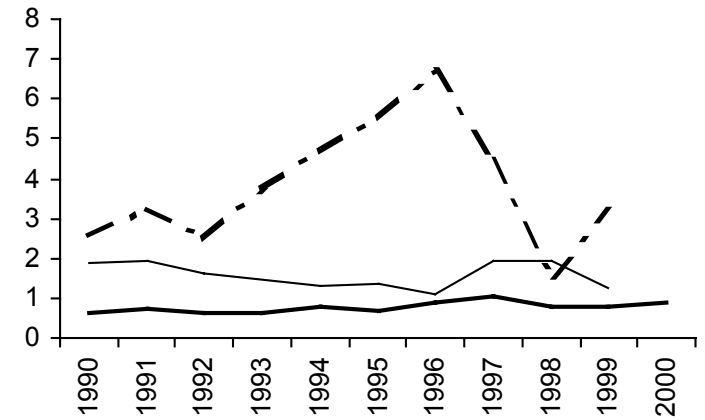

North Africa and Middle East

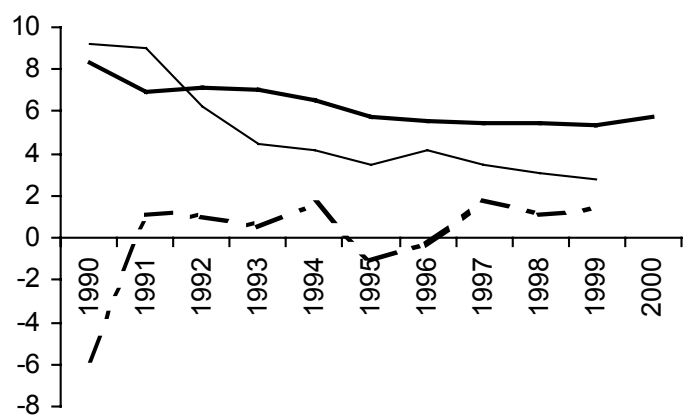

North America and Europe

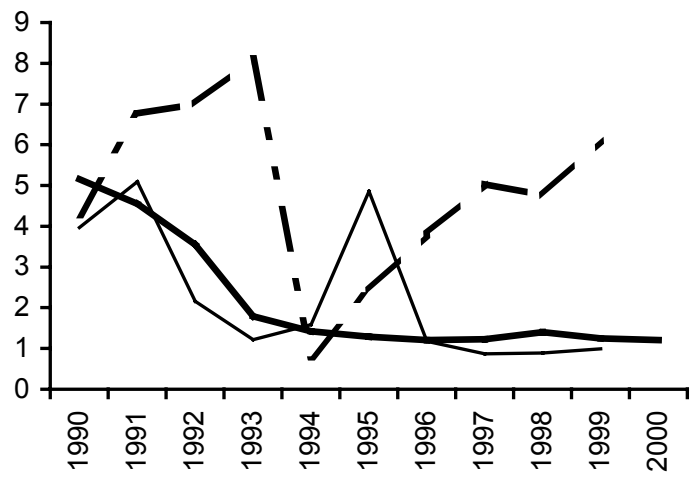

Latin America and the Carribean

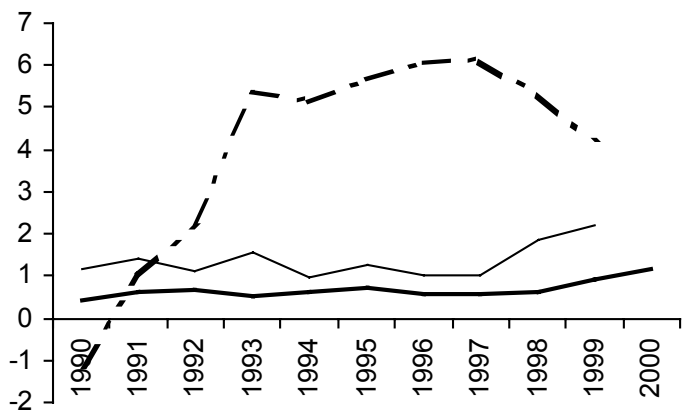

Sub-Saharan Africa

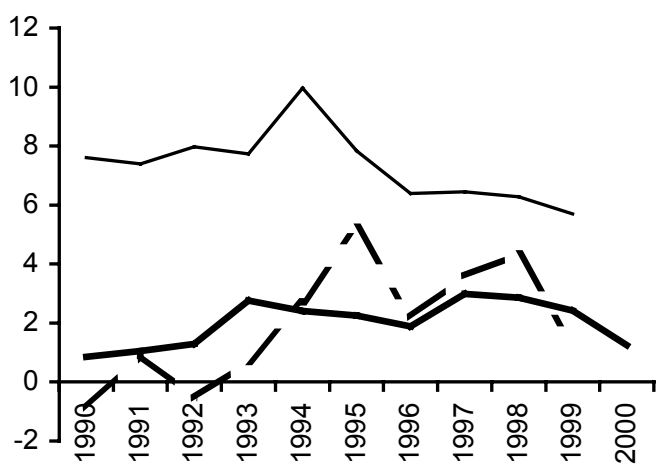


b) By Country

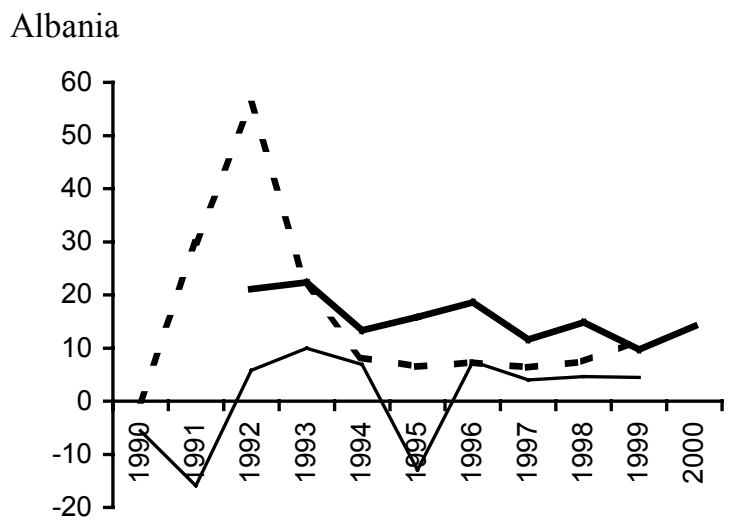

Cap Verde

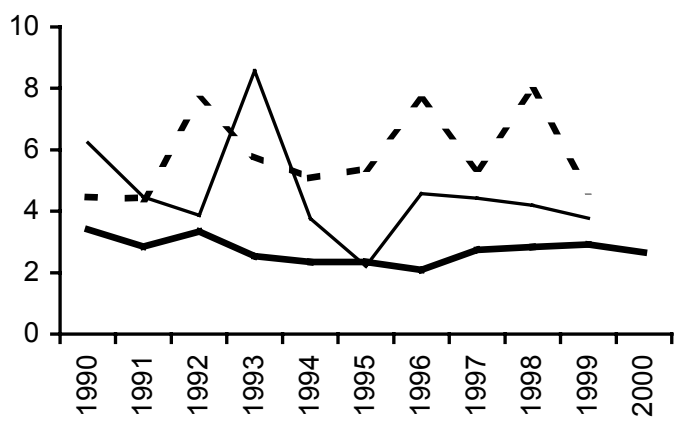

Dominican Republic

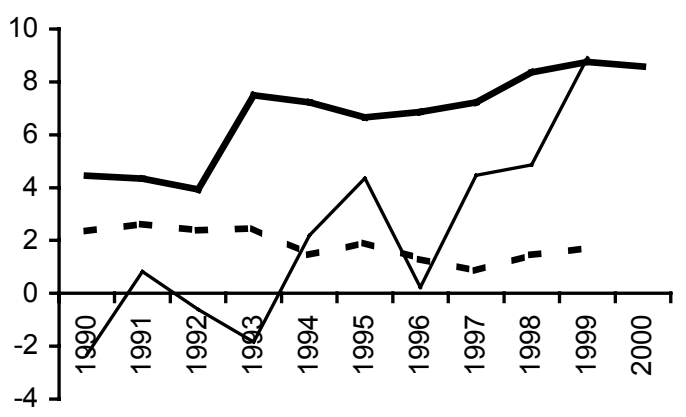

El Salvador

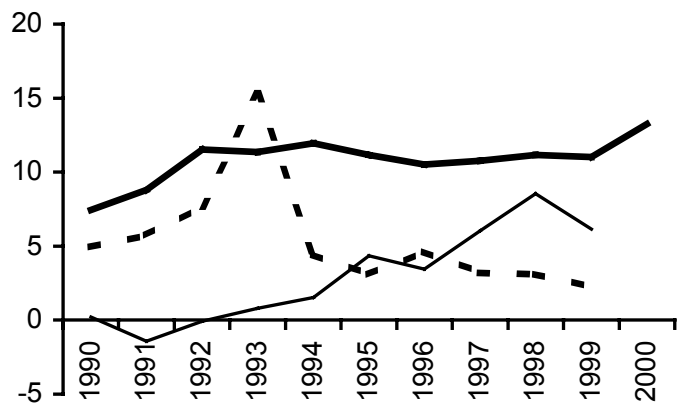

Belize

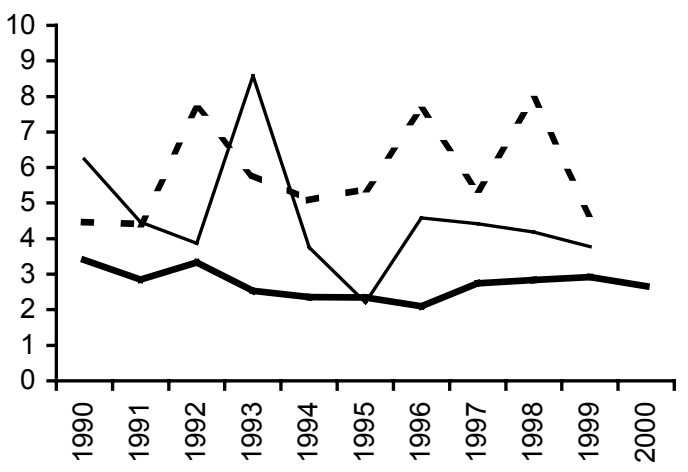

Croatia

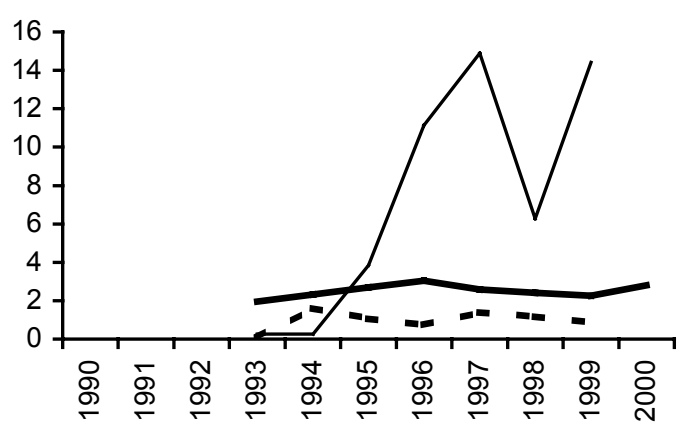

Jordan

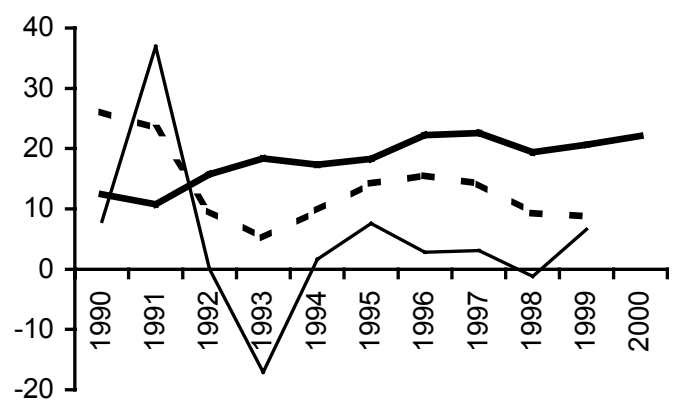

Jamaica

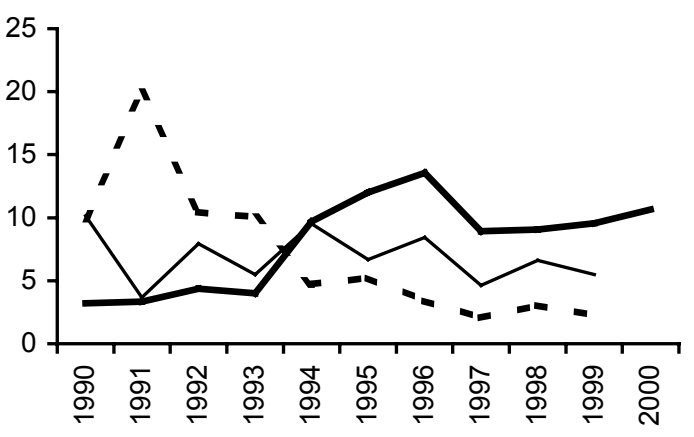

Remittances - - Official Capital Flows 
Table 1 - Developing Countries in the Sample

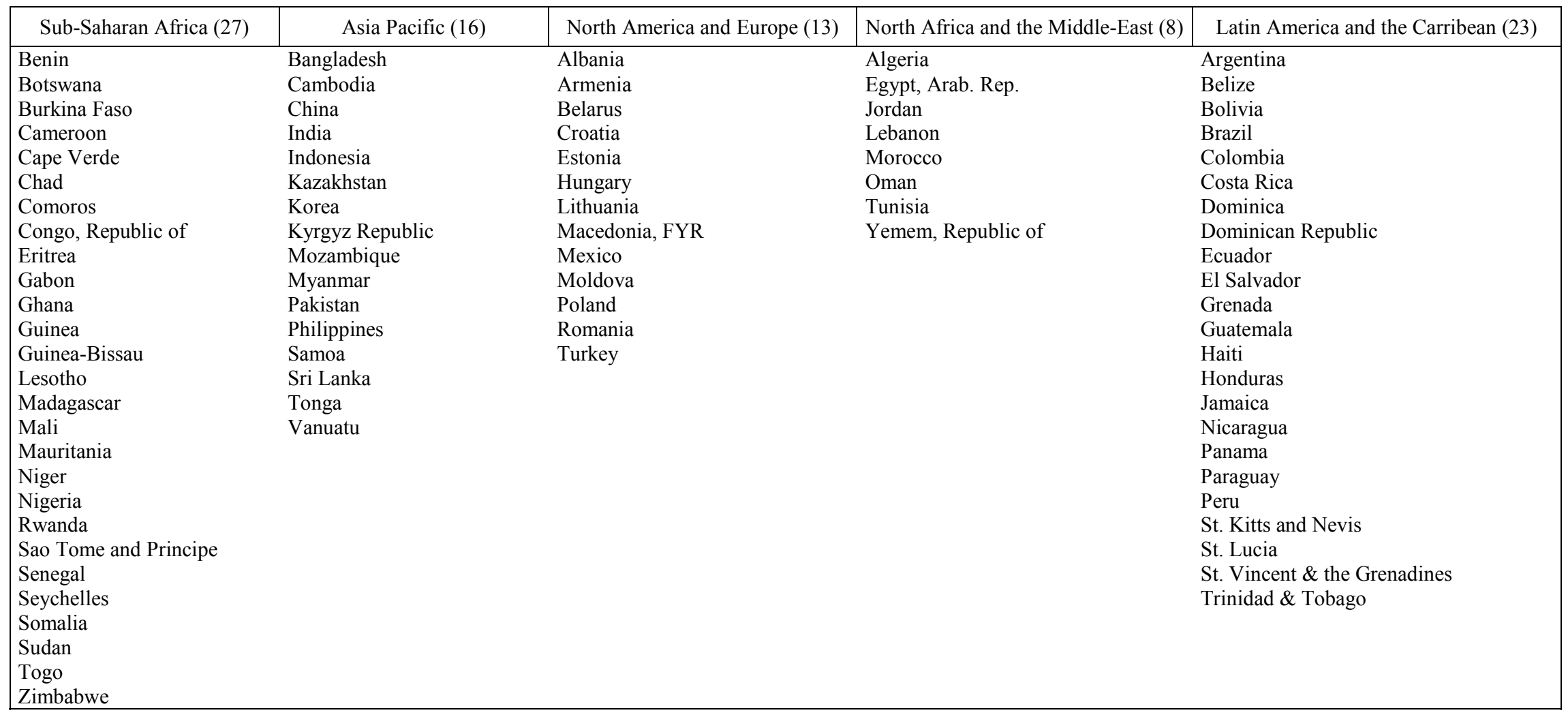


Table 2 - Estimation Results

This Table presents the results of the following regression:

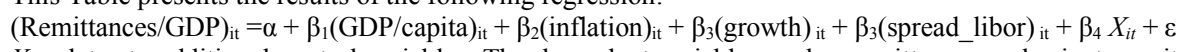

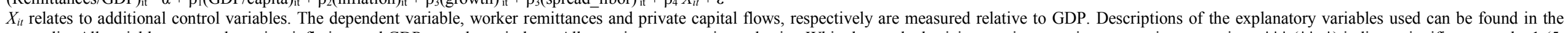

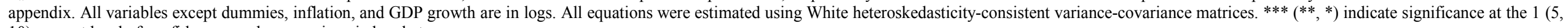
10) percent level of confidence. $t$-values are given in brackets.

\begin{tabular}{|c|c|c|c|c|c|c|c|c|c|c|c|c|}
\hline & \multicolumn{4}{|c|}{ Private Capital Flows } & \multicolumn{4}{|c|}{ Remittances } & \multicolumn{4}{|c|}{ Official Capital Flows } \\
\hline & Full sample & $1970 \mathrm{~s}$ & $1980 \mathrm{~s}$ & $1990 \mathrm{~s}$ & full sample & $1970 \mathrm{~s}$ & $1980 \mathrm{~s}$ & $1990 \mathrm{~s}$ & full sample & $1970 \mathrm{~s}$ & $1980 \mathrm{~s}$ & $1990 \mathrm{~s}$ \\
\hline GDP & $\begin{array}{l}-0.03 \\
(1.38)\end{array}$ & $\begin{array}{c}0.14 \\
(1.48)\end{array}$ & $\begin{array}{l}-0.05 \\
(1.09)\end{array}$ & $\begin{array}{c}0.04 \\
(1.42)\end{array}$ & $\begin{array}{l}-0.00 \\
(1.25)\end{array}$ & $\begin{array}{c}-0.04 * * \\
(2.50)\end{array}$ & $\begin{array}{l}-0.01 \\
(1.32)\end{array}$ & $\begin{array}{c}0.02 \\
(1.89)\end{array}$ & $\begin{array}{c}-0.04 * * \\
(2.33)\end{array}$ & $\begin{array}{l}0.08^{*} \\
(1.79)\end{array}$ & $\begin{array}{c}0.03 \\
(1.23)\end{array}$ & $\begin{array}{c}-0.12 * * * \\
(5.60)\end{array}$ \\
\hline LoögGDP per capita & $\begin{array}{c}-0.61^{*} \\
(1.68)\end{array}$ & $\begin{array}{c}6.49 * * * \\
(3.62)\end{array}$ & $\begin{array}{c}0.61 \\
(0.89)\end{array}$ & $\begin{array}{l}-0.26 \\
(0.77)\end{array}$ & $\begin{array}{c}-0.63 * * * \\
(3.50)\end{array}$ & $\begin{array}{c}-1.06^{* * *} \\
(2.74)\end{array}$ & $\begin{array}{l}-0.00 \\
(0.01)\end{array}$ & $\begin{array}{c}-0.81 * * * \\
(4.05)\end{array}$ & $\begin{array}{c}-2.31 * * * \\
(6.72)\end{array}$ & $\begin{array}{l}-2.84 \\
(1.02)\end{array}$ & $\begin{array}{c}-2.23 * * * \\
(7.22)\end{array}$ & $\begin{array}{c}-2.37 * * * \\
(7.20)\end{array}$ \\
\hline Inflation & $\begin{array}{c}0.00 \\
(0.70)\end{array}$ & $\begin{array}{c}-0.13 * * * \\
(5.19)\end{array}$ & $\begin{array}{c}0.00 * * * \\
(3.61)\end{array}$ & $\begin{array}{c}0.00 \\
(0.70)\end{array}$ & $\begin{array}{c}0.00 \\
(0.02)\end{array}$ & $\begin{array}{l}-0.00 \\
(0.01)\end{array}$ & $\begin{array}{c}0.00 \\
(0.30)\end{array}$ & $\begin{array}{l}-0.00 \\
(0.21)\end{array}$ & $\begin{array}{l}-0.00 \\
(1.55)\end{array}$ & $\begin{array}{c}-0.09 * * * \\
(5.95)\end{array}$ & $\begin{array}{c}0.00 \\
(0.17)\end{array}$ & $\begin{array}{c}0.01 * * * \\
(3.96)\end{array}$ \\
\hline Spread over_libor & $\begin{array}{l}-0.00 \\
(0.11)\end{array}$ & $\begin{array}{c}-0.53 * * * \\
(3.99)\end{array}$ & $\begin{array}{c}-0.00 * * * \\
(3.65)\end{array}$ & $\begin{array}{l}-0.00 \\
(0.63)\end{array}$ & $\begin{array}{l}-0.00 \\
(1.08)\end{array}$ & $\begin{array}{l}-0.04 \\
(1.17)\end{array}$ & $\begin{array}{l}-0.00 \\
(0.48)\end{array}$ & $\begin{array}{c}0.00 \\
(0.04)\end{array}$ & $\begin{array}{c}-0.00 * \\
(1.67)\end{array}$ & $\begin{array}{c}-0.26 * * * \\
(2.88)\end{array}$ & $\begin{array}{c}0.00 * * * \\
(12.57)\end{array}$ & $\begin{array}{c}-0.01 * * * \\
(4.28)\end{array}$ \\
\hline Island dummy & $\begin{array}{c}0.88 \\
(1.10)\end{array}$ & $\begin{array}{c}0.42 \\
(0.10)\end{array}$ & $\begin{array}{c}2.48 \\
(1.62)\end{array}$ & $\begin{array}{c}0.77 \\
(0.94)\end{array}$ & $\begin{array}{c}0.07 \\
(0.17)\end{array}$ & $\begin{array}{c}4.31 * * * \\
(4.44)\end{array}$ & $\begin{array}{c}0.52 \\
(1.54)\end{array}$ & $\begin{array}{l}-0.16 \\
(0.38)\end{array}$ & $\begin{array}{c}1.67 * * * \\
(2.72)\end{array}$ & $\begin{array}{c}1.76 \\
(0.39)\end{array}$ & $\begin{array}{c}4.92 * * * \\
(7.36)\end{array}$ & $\begin{array}{c}1.21 * * * \\
(2.89)\end{array}$ \\
\hline Asia & $\begin{array}{l}-1.53 \\
(1.43)\end{array}$ & $\begin{array}{c}0.40 \\
(0.10)\end{array}$ & $\begin{array}{l}-4.65 \\
(0.79)\end{array}$ & $\begin{array}{c}-2.18^{* *} \\
(2.21)\end{array}$ & $\begin{array}{l}-0.35 \\
(0.89)\end{array}$ & $\begin{array}{c}-7.80 * * * \\
(7.04)\end{array}$ & $\begin{array}{l}0.85 * \\
(1.76)\end{array}$ & $\begin{array}{l}-0.60 \\
(1.44)\end{array}$ & $\begin{array}{c}-3.25 * * * \\
(3.38)\end{array}$ & $\begin{array}{l}-5.60 \\
(0.93)\end{array}$ & $\begin{array}{c}-5.35 * * * \\
(7.75)\end{array}$ & $\begin{array}{c}-4.80 * * * \\
(5.94)\end{array}$ \\
\hline Latin & $\begin{array}{l}-1.19 \\
(0.97)\end{array}$ & $\begin{array}{l}-9.65^{*} \\
(1.93)\end{array}$ & $\begin{array}{l}-4.82 \\
(0.76)\end{array}$ & $\begin{array}{l}-0.32 \\
(0.31)\end{array}$ & $\begin{array}{c}0.16 \\
(0.40)\end{array}$ & $\begin{array}{c}-8.02 * * * \\
(5.41)\end{array}$ & $\begin{array}{l}1.07 * * \\
(2.03)\end{array}$ & $\begin{array}{l}-0.06 \\
(0.13)\end{array}$ & $\begin{array}{c}0.32 \\
(0.38)\end{array}$ & $\begin{array}{c}8.10 \\
(1.25)\end{array}$ & $\begin{array}{c}1.03 \\
(1.35)\end{array}$ & $\begin{array}{c}-1.47 * \\
(1.71)\end{array}$ \\
\hline Africa & $\begin{array}{l}-0.74 \\
(0.62)\end{array}$ & $\begin{array}{l}-1.40 \\
(0.43)\end{array}$ & $\begin{array}{l}-3.04 \\
(0.46)\end{array}$ & $\begin{array}{l}-1.37 \\
(1.20)\end{array}$ & $\begin{array}{c}0.34 \\
(0.64)\end{array}$ & $\begin{array}{c}-6.36^{* * *} \\
(6.38)\end{array}$ & $\diamond$ & $\begin{array}{c}0.33 \\
(0.62)\end{array}$ & $\begin{array}{c}0.61 \\
(0.53)\end{array}$ & $\begin{array}{l}-2.11 \\
(0.39)\end{array}$ & $\diamond$ & $\begin{array}{l}-1.52 \\
(1.37)\end{array}$ \\
\hline East & $\begin{array}{c}0.35 \\
(0.21)\end{array}$ & $\diamond$ & $\begin{array}{l}-3.16 \\
(0.48)\end{array}$ & $\begin{array}{l}-0.33 \\
(0.18)\end{array}$ & $\begin{array}{l}2.91 * * \\
(2.42)\end{array}$ & $\diamond$ & $\begin{array}{c}4.48 * * * \\
(6.60)\end{array}$ & $\begin{array}{c}6.02 * * * \\
(4.67)\end{array}$ & $\begin{array}{c}1.31 \\
(0.95)\end{array}$ & $\diamond$ & $\begin{array}{l}-1.36^{*} \\
(1.85)\end{array}$ & $\begin{array}{c}-3.14^{* *} \\
(2.06)\end{array}$ \\
\hline Female Labour & $\begin{array}{c}0.04 \\
(0.94)\end{array}$ & $\begin{array}{c}0.74 * * * \\
(6.72)\end{array}$ & $\begin{array}{c}0.02 \\
(0.30)\end{array}$ & $\begin{array}{c}0.07 \\
(1.56)\end{array}$ & $\begin{array}{l}-0.04 \\
(1.63)\end{array}$ & $\begin{array}{c}0.19 * * * \\
(3.58)\end{array}$ & $\begin{array}{c}0.06^{* *} \\
(2.44)\end{array}$ & $\begin{array}{c}-0.08 * * * \\
(4.20)\end{array}$ & $\begin{array}{c}0.06 \\
(1.52)\end{array}$ & $\begin{array}{c}0.29 \\
(1.57)\end{array}$ & $\begin{array}{c}0.09 * * * \\
(4.35)\end{array}$ & $\begin{array}{l}-0.05 \\
(0.99)\end{array}$ \\
\hline Age dependency & $\begin{array}{c}0.46 \\
(0.20)\end{array}$ & $\begin{array}{c}-23.99 * * \\
(2.52)\end{array}$ & $\begin{array}{c}5.38 \\
(1.35)\end{array}$ & $\begin{array}{l}-1.03 \\
(0.43)\end{array}$ & $\begin{array}{c}-2.47^{* *} \\
(2.21)\end{array}$ & $\begin{array}{c}-9.72 * * * \\
(3.58)\end{array}$ & $\begin{array}{c}1.33 \\
(1.11)\end{array}$ & $\begin{array}{l}-0.34 \\
(0.28)\end{array}$ & $\begin{array}{c}8.47^{* * *} \\
(3.95)\end{array}$ & $\begin{array}{c}0.46 \\
(0.04)\end{array}$ & $\begin{array}{c}-4.33^{* *} \\
(2.15)\end{array}$ & $\begin{array}{c}8.32 * * * \\
(3.85)\end{array}$ \\
\hline illiteracy & $\begin{array}{l}-0.00 \\
(0.07)\end{array}$ & $\begin{array}{c}0.09^{* *} \\
(2.12) \\
-\end{array}$ & $\begin{array}{c}-0.02 \\
(0.55) \\
\diamond\end{array}$ & $\begin{array}{l}-0.03 \\
(1.55)\end{array}$ & $\begin{array}{l}-0.00 \\
(0.29)\end{array}$ & $\begin{array}{c}0.04 * * * \\
(3.58)\end{array}$ & $\begin{array}{c}0.02 * * * \\
(3.02)\end{array}$ & $\begin{array}{c}-0.02 * \\
(1.77)\end{array}$ & $\begin{array}{l}-0.03 \\
(1.47)\end{array}$ & $\begin{array}{l}-0.08 \\
(1.10)\end{array}$ & $\begin{array}{l}0.04 * * \\
(2.39)\end{array}$ & $\begin{array}{l}0.03 * \\
(1.68)\end{array}$ \\
\hline Constant & $\begin{array}{l}-0.58 \\
(0.15)\end{array}$ & $\begin{array}{c}43.83 * * * \\
(3.35)\end{array}$ & & $\begin{array}{c}5.87 \\
(1.51)\end{array}$ & $\begin{array}{c}8.41 * * * \\
(3.77)\end{array}$ & $\begin{array}{c}12.93 * * * \\
(4.91)\end{array}$ & $\begin{array}{l}-3.70 \\
(1.54)\end{array}$ & $\begin{array}{c}11.06^{* * *} \\
(4.84)\end{array}$ & $\begin{array}{c}13.70 * * * \\
(3.30)\end{array}$ & $\begin{array}{l}20.17 \\
(0.81)\end{array}$ & $\begin{array}{c}22.43 * * * \\
(6.74)\end{array}$ & $\begin{array}{c}19.76 * * * \\
(4.56)\end{array}$ \\
\hline Observations & 853 & 64 & 348 & 437 & 741 & 52 & 288 & 397 & 862 & 66 & 354 & 438 \\
\hline \# countries & 59 & 20 & 42 & 56 & 61 & 18 & 37 & 57 & 59 & 20 & 42 & 56 \\
\hline
\end{tabular}

$\diamond$ Dropped due to collinearity 
Table 3 - Correlation Analysis (1970-2000)

\begin{tabular}{|l|c|c|c|}
\hline & $\begin{array}{c}\text { Workers' remittances } \\
\text { to private capital } \\
\text { inflows }\end{array}$ & $\begin{array}{c}\text { Workers' remittances } \\
\text { to official capital } \\
\text { inflows }\end{array}$ & $\begin{array}{c}\text { Private to official } \\
\text { capital inflows }\end{array}$ \\
\hline World & -0.01 & $0.29^{*}$ & $0.10^{*}$ \\
Asia Pacific & 0.03 & $0.51^{*}$ & $0.33^{*}$ \\
$\begin{array}{l}\text { Latin America and the } \\
\text { Carribean }\end{array}$ & -0.06 & $0.30^{*}$ & 0.03 \\
$\begin{array}{l}\text { North Africa and the Middle } \\
\text { East }\end{array}$ & 0.17 & $0.51^{*}$ & $0.25^{*}$ \\
North America and Europe & 0.01 & $0.60^{*}$ & $0.22^{*}$ \\
Sub-Saharan Africa & -0.06 & $0.20^{*}$ & $0.33^{*}$ \\
\hline
\end{tabular}

Note: * indicates significance at 5 percent level. All variables in terms of GDP.

Source: IMF (2002a, 2002b) and World Bank (2002). 
Table 4 - Mean and Coefficient of Variation (in percent unless indicated otherwise, 1970-2000)

\begin{tabular}{|c|c|c|c|c|c|c|}
\hline Variables & World & Asia Pacific & $\begin{array}{c}\text { Latin America and } \\
\text { the Carribean }\end{array}$ & $\begin{array}{c}\text { North Africa and the } \\
\text { Middle East }\end{array}$ & \begin{tabular}{|c|}
$\begin{array}{c}\text { North America } \\
\text { and Europe }\end{array}$ \\
\end{tabular} & $\begin{array}{c}\text { Sub-Saharan } \\
\text { Africa }\end{array}$ \\
\hline \multirow{4}{*}{$\begin{array}{l}\text { Workers' remittances } \\
\text { official capital } \\
\text { inflows } \\
\text { private capital flows }\end{array}$} & \multicolumn{6}{|c|}{ Variables in $\%$ of GDP } \\
\hline & 3.71 & 3.94 & 3.11 & 8.92 & 2.10 & 2.55 \\
\hline & 7.70 & 5.66 & 5.90 & 7.85 & 3.32 & 11.52 \\
\hline & 6.46 & 5.39 & 8.50 & 5.93 & 5.10 & 5.52 \\
\hline \multirow{4}{*}{$\begin{array}{l}\text { Workers' remittances } \\
\text { official capital } \\
\text { inflows } \\
\text { private capital flows }\end{array}$} & \multicolumn{6}{|c|}{ Growth rate of mean (variables in \% of GDP; 1970 s to 1990 s) } \\
\hline & 64 & 114 & 83 & 62 & -3 & 115 \\
\hline & 26 & -3 & 101 & -33 & 301 & -86 \\
\hline & 20 & 125 & 1 & -12 & 537 & 27 \\
\hline \multirow{4}{*}{$\begin{array}{l}\text { Workers' remittances } \\
\text { official capital } \\
\text { inflows } \\
\text { private capital flows }\end{array}$} & \multicolumn{6}{|c|}{ Coefficient of variation (variables in \% of GDP) } \\
\hline & 158 & 152 & 108 & 114 & 195 & 177 \\
\hline & 110 & 90 & 131 & 92 & 171 & 85 \\
\hline & 217 & 156 & 265 & 96 & 97 & 113 \\
\hline
\end{tabular}

Source: IMF (2002a, 2002b) and World Bank (2002). 
Table 5 - Volatility of Remittances, Private and Official Capital Inflows Across Countries (Average 1970-2000)

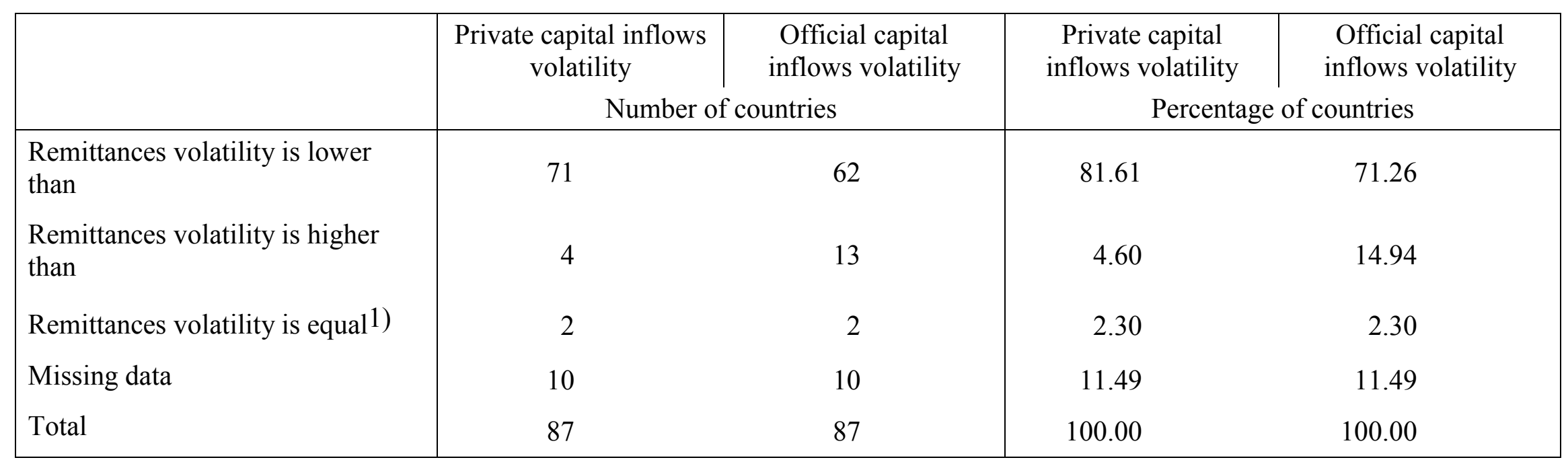

1) Difference is five-percentage points or less.

Source: IMF (2002a, 2002b). 


\section{Appendix II: Description of Data}

\section{Global Development Finance}

- Remittances are the monies that migrants return to the country of origin. If Labour is considered an export, than remittances are that part of the payment for exporting Labour services that returns to the country of origin. The International Monetary Fund (IMF) separates remittances into three categories: (i) workers' remittances, from workers who have lived abroad for more than one year; (ii) compensation of employees or Labour income, including wages and other compensation received by migrants who have lived abroad for less than one year; and (iii) migrant's transfers, the net worth of migrants who move from one country to another. To construct our dataset, we used workers' remittances (B19A..9) from the IMF Balance of Payments Statistics Yearbook.

It is worth noting the weaknesses of existing data on remittances. These numbers likely underrepresent the scale of remittances since many countries, and particularly low income countries for which remittances are important, have no processes or inadequate ones for estimating or reporting on the funds remitted by workers from abroad. Furthermore, a large share of remittances is not channeled through formal banking systems, but rather through a myriad of informal channels, such as postal money orders. Remittances can be in-kind (including consumer goods, capital goods and skills, and technological knowledge) and clandestine. Correcting for underreporting, Korovilas (1999), for instance, estimated that total remittances in Albania exceed the official number by approximately $75 \%$ in the early $1990 \mathrm{~s}$.

Our estimated aggregated figures do not reflect the ones published by the IMF Balance of Payments Statistics Yearbook, but consist of the sum of all published data on a country-bycountry basis. Thus, if a country does not report on time its amount of workers' remittances, the IMF will add a proxy for that country to his estimated total aggregated amount.

\section{- Private net resource flows (US\$)}

Private net resource flows are the sum of net flows on debt to private creditors (PPG and PNG) plus net direct foreign investment and portfolio equity flows. Net flows (or net lending or net disbursements) are disbursements minus principal repayments.

- Official net resource flows (US\$)

Official net resource flows are the sum of official net flows on long-term debt to official creditors (excluding IMF) plus official grants (excluding technical cooperation). Net flows (or net lending or net disbursements) are disbursements minus principal repayments.

\section{World Development Indicators}

- GDP per capita (constant 1995 US\$)

GDP per capita is gross domestic product divided by midyear population. GDP is the sum of gross value added by all resident producers in the economy plus any product taxes and minus any subsidies not included in the value of the products. It is calculated without making deductions for depreciation of fabricated assets or for depletion and degradation of natural resources. Data are in constant U.S. dollars. 
- GDP (constant 1995 US\$)

GDP is the sum of gross value added by all resident producers in the economy plus any product taxes and minus any subsidies not included in the value of the products. It is calculated without making deductions for depreciation of fabricated assets or for depletion and degradation of natural resources. Data are in constant 1995 U.S. dollars. Dollar figures for GDP are converted from domestic currencies using 1995 official exchange rates. For a few countries where the official exchange rate does not reflect the rate effectively applied to actual foreign exchange transactions, an alternative conversion factor is used.

- Inflation, GDP deflator (annual \%)

Inflation as measured by the annual growth rate of the GDP implicit deflator shows the rate of price change in the economy as a whole. The GDP implicit deflator is the ratio of GDP in current local currency to GDP in constant local currency.

- Population: We used the data published in the International Finance Statistics database (99Z..ZF)

- Human Development Index is published in the Human Development Report Office 2000 and is composed of three indicators: longevity, as measured by life expectancy at birth; educational attainment, as measured by a combination of the adult literacy rate (two-thirds weight) and the combined gross primary, secondary and tertiary enrolment ratio (one-third weight); and standard of living, as measured by GDP per capita (PPP US\$).

- GDP Growth: annual percentage growth of GDP (own calculations).

- Female Labour: Female labor force as a percentage of the total shows the extent to which women are active in the labor force. Labor force comprises all people who meet the International Labour Organization's definition of the economically active population.

- Spread of the Domestic Lending Rate over Libor: Interest rate spread is the interest rate charged by banks on loans to prime customers minus the interest rate paid by commercial or similar banks for demand, time, or savings deposits. Spread over LIBOR (London Interbank Offer Rate) is the interest $r$ ate charged by banks on loans to prime customers minus LIBOR. LIBOR is the most commonly recognized international interest rate and is quoted in several currencies. The average three-month LIBOR on U.S. dollar deposits is used here.

- Age Dependency Ratio: Age dependency ratio is calculated as the ratio of dependents--the population under age 15 and above age 65--to the working-age population--those aged 15-64. For example, 0.7 means there are 7 dependents for every 10 working-age people.

- Illiteracy: Adult illiteracy rate is the proportion of adults aged 15 and above who cannot, with understanding, read and write a short, simple statement on their everyday life. 